\title{
Helplessness of Rural and Urban People
}

\author{
Mr. Hardik Patel ${ }^{1}$
}

\section{ABSTRACT:}

Present research has done to know the effect of rural and urban people on helplessness. For this total number of sample was 240 sample was selected from anand district. For the data collection Helplessness scale by G P Mathur and Raj Kumari Bhatnagar was used. Data was analysis and concluded result by ' $t$ ' test. Result show, There is no significant difference between rural and urban people on helplessness.

Keywords: Helplessness, Rural and Urban People

\section{Meaning of learned helplessness}

Learned helplessness is a mental state in which an organism forced to endure aversive stimuli, or stimuli that are painful or otherwise unpleasant becomes unable or unwilling to avoid subsequent encounters with these stimuli even if they are escapable, presumably because it has learned that it cannot control the view that clinical depression and related mental illnesses may result from a perceived absence of control over the outcome of a situation. Organisms that have been ineffective and less sensitive in determining the consequences of their behaviour are defined as having acquired learned helplessness.

\section{Learned Helplessness}

The model of learned helplessness given by Seligman(1973) describes states of helplessness that exist in humans who have experienced numerous failures ( either real or perceived ). The individual abandons any further attempts toward success. Seligman theorized that learned helplessness predisposes individuals to depression by imposing a feeling of lack of control over their life situations (McKinney \& Moran, 1982). It has been empirically proven that negative expectations about the effectiveness of one's own efforts in bringing about the control over one's own environment leads to passivity and diminished initiation of responses (Abrahmson, Seligman \& Teasdale, 1978). The term learned helplessness describes an organism's reaction when it is faced with important events that cannot be altered by its voluntary responses. Learned helplessness is both a behavioral state and a personality trait of one who believes that control has been lost over the reinforces in the environment. These negative expectations lead to helplessness, passivity and an inability to assert oneself.

\footnotetext{
${ }^{1} \mathrm{Ph}$. D. Researcher Scholar, Department of Psychology,Sardar Patel University
} 
Learned helplessness is a psychological condition in which a human or animal has learned to believe that they are helpless. They feel that they have no control over their situation and that whatever they do is futile. As a result, they will stay passive when the situation is unpleasant, harmful or damaging. Learned helplessness undermines motivation and retards the ability to perceive success (Seligman, 1975). Martin Seligman developed the theory of depression in the mid 1960's. The theory has two main points, people become depressed when they think that they no longer have control over the reinforcements (the rewards and punishments) in their lives and that they themselves are responsible for this helpless state. Not all people become depressed as a result of being in a situation where they appear not to have control. Seligman discovered that a depressed person thought about the bad event in more pessimistic ways than a non depressed person. He called this thinking, "explanatory style".

People in a state of learned helplessness view problems as personal, pervasive, or permanent. That is, Personal they may see themselves as the problem; that is, they have internalized the problem. Pervasive they may see the problem as affecting all aspects of life. Permanent they may see the problem as unchangeable. It is a motivational problem where one might have failed in a task or two in the past which have made that individual believe that they are incapable to do anything in order to improve their performance in that task (Stipek \& Freeman, 1988).

\section{PROBLEM OF STUDY}

The problem of the present study is an under:

\section{"HELPLESSNESS OF RURAL AND URBAN PEOPLE"}

\section{OBJECTIVE OF THE STUDY}

1. To study of the helplessness among rural and urban people

\section{HYPOTHESIS}

1. There will be no difference between rural and urban people on helplessness.

\section{METHODOLOGY}

\section{Sample}

For this research total number of sample was 240 samples was selected from anand district. Which are 125 rural area and 115 urban area people selected.

\section{Tools}

The following tools were used in the present study.

\section{Personal datasheet}

Certain personal information about respondents included in the sample of research is useful and important for research. Here also, for collecting such important information, personal data sheet was prepared. With the help of this personal data sheet, the information about sex, area and type of family. 


\section{Helplessness scale}

The Helplessness scale developed by G P Mathur and Raj Kumari Bhatnagar was used. The scale consists 22 items in eight Areas. It was administrated on age group of 14+ In this test the Reliability coefficient has been found to be male reliability ranges $0.77-0.83$ and female $0.75-.80$. by test retest method and the author has reported satisfactory validity of the questionnaire.

\section{STATISTICAL ANALYSIS}

Following statistical analysis will be used for analyzing the data ' $\mathrm{t}$ ' - test

\section{RESULT AND DISCUSSION}

Table: 1

$\mathrm{N}=\mathbf{2 4 0}$

Means, SDs and ' $t$ ' value of Helplessness with reference to rural and urban

\begin{tabular}{|l|l|l|l|l|l|l|}
\hline Variable & Group & $\mathrm{N}$ & Mean & SD & 't' & Significant level \\
\hline \multirow{2}{*}{ Helplessness } & Rural & 125 & 66.21 & 7.24 & 1.29 & NS \\
\cline { 2 - 5 } & Urban & 115 & 67.43 & 7.46 & & \\
\hline
\end{tabular}

It is revealed in Table no. 1 that mean score of helplessness belonging to rural and urban area people are 66.21 and 67.43 respectively. These means indicate that urban area people experienced the highest level of helplessness (67.43) as compared to the rural area people (66.21). The results indicate this as first sight. when ' $t$ ' value was calculated to know statistical significant of mean difference, non-significant difference was observed between rural and urban area people. ' $t$ ' value is 1.29 which is statistically non-significant. Hence the null hypothesis was accepted. Thus the results show that area has no significant effect on helplessness.

\section{CONCLUSION:}

1. There is no significant difference between rural and urban area people on helplessness.

\section{REFERENCES:}

1. Usha (2012) Hardiness, self-esteem and learned helplessness in relation to alcohol use, a published thesis Punjabi university.

2. Seligman, M. E. P. (1975). Helplessness: On Depression, Development, and Death. San Francisco: W. H. Freeman. ISBN 0-7167-2328-X 
3. Hiroto, D.S.; Seligman, M.E.P. (1975). "Generality of learned helplessness in man". Journal of Personality and Social Psychology 31: 311-27.

4. Peterson, C.; Park, C. (1998). "Learned helplessness and explanatory style". In Barone, D. F.; Hersen, M.; VanHasselt, V. B. Advanced Personality. New York: Plenum Press. pp. 287-308. ISBN 0-306-45745-8.

5. Cole, C. S.; Coyne, J. C. (1977). "Situational specificity of laboratory-induced learned helplessness in humans". Journal of Abnormal Psychology 86 (6): 615-623.

6. Mathur G.P and R. Bhatnagar. helplessness Scale. Agra: national psychological corporation, 2004. 